\title{
Purification and Partial Characterization of Hyaluronate Lyase (EC 4.2.2.1) from Propionibacterium acnes
}

\author{
By EILEEN INGHAM ${ }^{1}$, K. T. HOLLAND 2 , G. GOWLAND ${ }^{1}$ \\ AND W. J. CUNLIFFE ${ }^{3}$ \\ University Departments of Immunology $y^{1}$, Microbiology $y^{2}$ and Dermatology, \\ The General Infirmary, Leeds LS1 3EX
}

(Received 5 March 1979; revised 30 April 1979)

\begin{abstract}
Hyaluronidase from Propionibacterium acnes has been purified 13000-fold from the culture supernatant to homogeneity (as determined by polyacrylamide disc gel electrophoresis). The molecular weight of the purified enzyme was 85110 as determined by gel filtration. The purified enzyme had a $\mathrm{pH}$ optimum at 6.4 , was stable between $\mathrm{pH} 5$ and 5.8 and was completely inactivated after $15 \mathrm{~min}$ at $50{ }^{\circ} \mathrm{C}$. Preliminary studies suggested that the enzyme is active against chondroitin 4- and 6-sulphates, but not against dermatan sulphate. Analysis by paper chromatography of the reaction products from the degradation of hyaluronic acid by bacterial, testicular and $P$. acnes enzymes suggested that the $P$. acnes enzyme is similar in its mode of action to other bacterial hyaluronate lyases. The enzyme from $P$. acnes may thus be tentatively classified as a hyaluronate lyase.
\end{abstract}

\section{INTRODUCTION}

Propionibacterium acnes is the major bacterial inhabitant of the forehead and back of man (Marples \& McGinley, 1974) and has been implicated in the disease acne vulgaris (Kirschbaum \& Kligman, 1963). Propionibacterium acnes produces at least three exocellular enzymes: a lipase (Reisner et al., 1968), a protease (Marples \& McGinley, 1974) and a hyaluronidase (Smith \& Willet, 1968). Attention has been focused on the lipase because of its role in hydrolysing sebum triglycerides to free fatty acids. These acids may be effective in reducing the invasion of overt skin pathogens, but it has been suggested that they may, if over-produced, predispose to acne (Marples et al., 1971). The possible significance of other enzymes produced by $P$. acnes, either in normal or acne skin, has not been seriously considered and little is known about these enzymes.

The production of hyaluronidase by $P$. acnes was first noted by Smith \& Willet (1968). In a survey of enzymes produced by $P$. acnes and related bacteria, Hoeffler (1977) showed that $73 \%$ of $P$. acnes, $18 \%$ of $P$. avidum and $33 \%$ of $P$. granulosum strains tested produced hyaluronidase. Puhvel \& Reisner (1972) have shown that isolates of $P$. acnes from both normal skin and the skin of patients with cystic acne produce the enzyme in vitro. The $\mathrm{pH}$ optima and temperature stability of the enzymes from the various isolates were described in preparations of crude exocellular products, but no attempt was made to purify or characterize the enzyme.

To understand the function of this exoenzyme in the physiology of $P$. acnes and its effect on the skin environment, it was necessary to purify the hyaluronidase produced by a typical strain of $P$. acnes. 


\section{METHODS}

Reagents. Hyaluronic acid (grade III from human umbilical cord, $>98 \%$ pure, containing $<2 \%$ chon droitin sulphates), chondroitin 4 - and 6-sulphates ( $>98 \%$ pure), dermatan sulphate ( $>98 \%$ pure), $N$-acetyl-D-glucosamine, azocasein, triolein, bovine serum albumin fraction $\mathrm{V}$, ovalbumin, cytochrome $c$ (horse-heart, 95 to $100 \%$ pure), p-dimethylaminobenzaldehyde and sodium dodecyl sulphate were obtained from Sigma. Ammonium sulphate, acrylamide, methylene-bisacrylamide, 4-nitrophenyl disodium orthophosphate and the zwitterionic buffers 3-( $N$-morpholino)propanesulphonic acid (MOPS) and 2- $(N$-morpholino)ethanesulphonic acid (MES) were obtained from BDH. Sephadex G-200, G-100, CM-Sephadex C-50 and Blue Dextran 2000 were obtained from Pharmacia. All other chemicals were reagent grade.

Enzyme preparations. Testicular hyaluronidase type I, phosphorylase $a$ [from rabbit muscle, $2 \times$ crystallized, specific activity 25 units $\mathrm{mg}^{-1}$, containing $30 \%(\mathrm{w} / \mathrm{w}$ ) phosphorylase $b]$, $\beta$-galactosidase (from $E$. coli, $>98 \%$ pure, specific activity 850 units $\mathrm{mg}^{-1}$ ), pyruvate kinase (from rabbit muscle, $>98 \%$ pure, specific activity 400 to 500 units $\left.\mathrm{mg}^{-1}\right)$ and ribonuclease A $(5 \times$ crystallized, 95 to $98 \%$ pure, specific activity 50 to 100 Kunitz units $\mathrm{mg}^{-1}$ ) were obtained from Sigma. Yeast alcohol dehydrogenase [purified, containing $<0 \cdot 1 \%$ (w/w) impurities, specific activity about 400 units $\mathrm{mg}^{-1}$ ] was obtained from Boehringer. Staphylococcus aureus hyaluronate lyase was a generous gift from Dr A. W. Sim, Organon Laboratories, Oss, Holland.

Bacterial strain. A laboratory strain of $P$. acnes (type I of Marples \& McGinley, 1974) isolated from a blackhead lesion on a patient in Leeds General Infirmary, and designated P-37, was used throughout this study. Stock cultures were maintained in $40 \%(\mathrm{w} / \mathrm{v})$ glycerol in $0.1 \mathrm{M}$-potassium phosphate buffered saline (pH 7.3) at $-20^{\circ} \mathrm{C}$.

Enzyme production. Brain Heart Infusion broth (Difco) supplemented with $0.3 \%$ (w/v) glucose was dispensed in $400 \mathrm{ml}$ portions into bottles and sterilized at $121^{\circ} \mathrm{C}$ for $20 \mathrm{~min}$. Exponential phase culture $(0.5 \%, \mathrm{v} / \mathrm{v})$ of $\boldsymbol{P}$. acnes was added to each bottle and incubated without stirring in an atmosphere of $\mathrm{H}_{2} / \mathrm{CO}_{2}$ $(90: 10, v / v)$ in cold catalyst anaerobic jars at $37{ }^{\circ} \mathrm{C}$ for 6 to $7 \mathrm{~d}$. Culture supernatant containing the exocellular products was separated by centrifuging at $3000 \mathrm{~g}$ for $1 \mathrm{~h}$. This supernatant was used as a source of hyaluronidase and designated fraction I enzyme.

Hyaluronidase assay. Hyaluronidase was assayed by the appearance of $N$-acetylglucosamine end-group colour with umbilical cord hyaluronic acid as substrate. To $2.5 \mathrm{ml} 0.1 \mathrm{M}$-sodium acetate buffer (pH 6.4) was added $0.5 \mathrm{ml} 0.1 \%(\mathrm{w} / \mathrm{v})$ hyaluronic acid and $0.5 \mathrm{ml}$ of a suitable dilution of enzyme in the same buffer. After incubation at $37^{\circ} \mathrm{C}$ for $15 \mathrm{~min}, 0.5 \mathrm{ml}$ of this reaction mixture was added to $0.1 \mathrm{ml} 0.8 \mathrm{M}$-potassium tetraborate ( $\mathrm{pH} \mathrm{9 \cdot 2).} \mathrm{N}$-Acetylglucosamine end-group colour was determined by the method of Reissig et al. (1955) using $\mathrm{N}$-acetylglucosamine as the standard. No breakdown of hyaluronic acid occurred at $\mathrm{pH} 6.4$ in the absence of the enzyme. Substrate blank controls were included. Activity is expressed as $\mu$ mol $N$-acetylglucosamine released $\mathrm{min}^{-1}$.

Lipase assay. Lipase (EC 3.1.1.3) was assayed using triolein as substrate. The reaction mixture contained $0.5 \mathrm{ml}$ triolein emulsion [10\% (w/v) triolein emulsified in $5 \%(\mathrm{w} / \mathrm{v})$ gum acacia using a Polytron homogenizer at maximum speed for $1 \mathrm{~min}], 0.5 \mathrm{ml}$ enzyme solution and $2.5 \mathrm{ml} 0.1 \mathrm{M}$-citrate/phosphate buffer (pH 6.5). A $1 \mathrm{ml}$ portion of this reaction mixture was transferred to $5 \mathrm{ml}$ Dole's reagent before and after $1 \mathrm{~h}$ incubation at $37^{\circ} \mathrm{C}$. The amount of oleic acid released was determined by the method of Dole \& Meinertz (1960) using oleic acid as the standard. Activity is expressed as $\mu \mathrm{mol}$ oleic acid released min $^{\mathbf{- 1}}$.

Acid phosphatase assay. Acid phosphatase (EC 3.1.3.2) was assayed using 4-nitrophenyl disodium orthophosphate as substrate according to Bessey et al. (1946). The reaction mixture contained $0.5 \mathrm{ml} 1 \%$ $(\mathrm{w} / \mathrm{v})$ 4-nitrophenyl disodium orthophosphate, $0.5 \mathrm{ml}$ enzyme solution and $2.5 \mathrm{ml} 0.1 \mathrm{M}$-sodium acetate buffer ( $\mathrm{pH} \mathrm{5 \cdot 8)}$ ). A $1 \mathrm{ml}$ portion of this reaction mixture was transferred to $2 \mathrm{ml} 0.2 \mathrm{M}-\mathrm{NaOH}$ before and after $15 \mathrm{~min}$ incubation at $37^{\circ} \mathrm{C}$. The amount of 4-nitrophenol liberated was determined by recording the absorbance at $420 \mathrm{~nm}$ using 4-nitrophenol as the standard. Activity is expressed as $\mu \mathrm{mol}$ 4-nitrophenol produced $\mathrm{min}^{-1}$.

Protease assay. Protease was determined by the method of Millet (1970) using azocasein as substrate. The reaction mixture contained $1 \mathrm{ml} 1 \%(\mathrm{w} / \mathrm{v}$ ) azocasein in $0.1 \mathrm{M}-\mathrm{MES}(\mathrm{pH} 6.5)$ and $1 \mathrm{ml}$ enzyme solution. Trichloroacetic acid $(2 \mathrm{ml} ; 10 \%$ w/v) was added to control tubes at time zero and to assay tubes after up to $16 \mathrm{~h}$ incubation at $37^{\circ} \mathrm{C}$. After centrifugation and filtration, absorbances were recorded at $440 \mathrm{~nm}$. Enzyme blanks were included.

Enzyme purification. All procedures were carried out at $4{ }^{\circ} \mathrm{C}$.

(i) Ultrafiltration. Culturesupernatant was concentrated in an Amicon model TCF10Diaflo cell fitted with a PM10 Diaflo membrane (mol. wt cut-off 10000). At later stages in the purification, enzymically active fractions from various columns were concentrated and dialysed by ultrafiltration in a $50 \mathrm{ml}$ Amicon model 52 cell fitted with a PM10 membrane.

(ii) Ammonium sulphate precipitation. Solid $\left(\mathrm{NH}_{4}\right)_{2} \mathrm{SO}_{4}$ was added to the culture supernatant to give $40 \%$ 
saturation, the solution was stirred at $4{ }^{\circ} \mathrm{C}$ for $2 \mathrm{~h}$ then centrifuged at $3000 \mathrm{~g}$ for $30 \mathrm{~min}$. The supernatant was then brought to $50 \%$ saturation, stirred and centrifuged as above. The precipitate was dissolved in a minimum volume of $0 \cdot 1 \mathrm{M}$-sodium phosphate buffer $(\mathrm{pH} 6 \cdot 0)$ and desalted by ultrafiltration.

(iii) Column chromatography. $\left(\mathrm{NH}_{4}\right)_{2} \mathrm{SO}_{4}$-precipitated enzyme was loaded on to a Sephadex G-200 column $(2.6 \times 46 \mathrm{~cm})$ pre-equilibrated with $0.1 \mathrm{M}$-sodium phosphate buffer (pH 6.0). Fractions $(3.5 \mathrm{ml})$ were collected at a flow rate of $10 \mathrm{ml} \mathrm{h}^{-1}$. Those containing high enzyme activity were pooled and concentrated to $6 \mathrm{ml}$ by ultrafiltration and then loaded on to a Sephadex G-100 column $(2 \cdot 4 \times 31 \mathrm{~cm})$ pre-equilibrated with $0 \cdot 1 \mathrm{M}$-sodium phosphate buffer $\left(\mathrm{pH} \mathrm{6.0)}\right.$. Fractions $(4.5 \mathrm{ml})$ were collected at a flow rate of $10 \mathrm{ml} \mathrm{h}^{-1}$. Those containing high enzyme activity were dialysed by ultrafiltration against $50 \mathrm{~mm}-\mathrm{Tris} / \mathrm{HCl}$ buffer $(\mathrm{pH} \mathrm{7 \cdot 0)}$. The enzyme was then loaded on to a CM-Sephadex C-50 column $(2.4 \times 30 \mathrm{~cm})$ pre-equilibrated with the same buffer. The column was eluted with $100 \mathrm{ml} 50 \mathrm{~mm}$-Tris/ $\mathrm{HCl}(\mathrm{pH} 7.0)$ before applying a $400 \mathrm{ml}$ linear gradient of 0 to $0.3 \mathrm{M}-\mathrm{NaCl}$ in the same buffer. Fractions $(6 \mathrm{ml})$ were collected at a flow rate of $12 \mathrm{ml} \mathrm{h}^{-1}$. Those with constant specific activity (per mg protein) were combined, desalted by ultrafiltration and lyophilized.

Isoelectric focusing. Electrofocusing was carried out at $4{ }^{\circ} \mathrm{C}$ using an LKB $110 \mathrm{ml}$ capacity column with $1 \%(\mathrm{v} / \mathrm{v})$ ampholines ( $\mathrm{pH}$ range 3 to 10$)$. The column was prepared according to the manufacturer's instructions. Samples were dialysed against $1 \%(\mathrm{w} / \mathrm{v})$ glycine (adjusted to $\mathrm{pH} 6.8$ with $1 \mathrm{M}-\mathrm{HCl}$ ) and applied to the light fraction of the sucrose density gradient. Electrolysis was initiated by applying $300 \mathrm{~V}$ until a constant current of $2 \mathrm{~mA}$ was obtained $(24 \mathrm{~h})$. Fractions $(3 \mathrm{ml})$ were collected and the elution of protein was monitored spectrophotometrically. The $\mathrm{pH}$ of the fractions was determined using a Radiometer $\mathrm{pH}$ meter (model 26).

Polyacrylamide disc gel electrophoresis. The enzyme preparations were examined by polyacrylamide disc gel electrophoresis according to the method of Davis (1964). Protein bands were stained with $0.05 \%$ (w/v) Coomassie blue in methanol/acetic acid/water $(25: 10: 65$, by vol.).

Molecular weight determination. (i) Sephadex G-100 chromatography. A $31 \times 2.4 \mathrm{~cm}$ column equipped with a flow adaptor and pre-equilibrated with $0.1 \mathrm{M}$-sodium phosphate buffer (pH 6.0) was calibrated with $\beta$-galactosidase (mol. wt 130000), ovalbumin (mol. wt 43000) and ribonuclease A (mol. wt 13700). The void volume was determined with Blue Dextran 2000. A $2 \mathrm{ml}$ sample of purified fraction VI hyaluronidase (see Table 1) was loaded on to the column. Fractions $(2.5 \mathrm{ml})$ were collected at a flow rate of $10 \mathrm{ml} \mathrm{h}^{-1}$.

(ii) Sodium dodecyl sulphate (SDS)-polyacrylamide gel electrophoresis. SDS-polyacrylamide gel electrophoresis was carried out according to Weber et al. (1972) in $7.5 \%$ gels. Phosphorylase $a$ (mol. wt 94000), pyruvate kinase (mol. wt 57000), alcohol dehydrogenase (mol. wt 37000) and cytochrome $c$ (mol. wt 12384) were used as reference proteins. Samples $(10$ to $20 \mu \mathrm{g}$ protein in $50 \mu \mathrm{l})$ were prepared as described by Weber et al. (1972) by heating to $100^{\circ} \mathrm{C}$ for $2 \mathrm{~min}$ in $0.01 \mathrm{M}$-sodium phosphate buffer (pH 7.0) containing $1 \%(\mathrm{w} / \mathrm{v}) \mathrm{SDS}$ and $1 \%(\mathrm{w} / \mathrm{v}) 2$-mercaptoethanol.

Protein determination. The elution of protein from various columns was monitored at $280 \mathrm{~nm}$. Protein determinations were made by the method of Lowry using bovine serum albumin as the standard.

Preliminary studies to determine the reaction products of $P$. acnes hyaluronidase activity. The reaction products of $\boldsymbol{P}$. acnes hyaluronidase were compared with those of Staphylococcus aureus hyaluronate lyase and testicular hyaluronidase. Samples $(1 \mathrm{ml})$ of testicular hyaluronidase $\left(10 \mathrm{mg} \mathrm{ml}^{-1}\right), S$. aureus hyaluronate lyase $\left(10 \mathrm{mg} \mathrm{m}^{-1}\right)$ and fraction $\mathrm{V} P$. acnes enzyme $\left(0.15 \mathrm{mg} \mathrm{ml}^{-1}\right)$ were each incubated with $1 \mathrm{ml} 1 \%(\mathrm{w} / \mathrm{v})$ hyaluronic acid in $0.1 \mathrm{M}$-sodium acetate buffer $(\mathrm{pH} 6.4)$ at $37^{\circ} \mathrm{C}$ for $24 \mathrm{~h}$. The three enzyme digests were analysed by paper chromatography following the method of Linker et al. (1956). $N$-Acetylated derivatives were detected by spraying the dried chromatogram with $p$-dimethylaminobenzaldehyde $[1 \mathrm{~g}$ dissolved in $60 \mathrm{ml}$ ethanol/ $\mathrm{HCl}(1: 1, \mathrm{v} / \mathrm{v})$ and diluted with butan-1-ol to $180 \mathrm{ml}$ ] and heating the chromatogram to $90{ }^{\circ} \mathrm{C}$ for $10 \mathrm{~min}$ to develop the violet colour.

\section{RESULTS \\ Enzyme purification}

The purification of $P$. acnes hyaluronidase from 1.51 of culture supernatant is summarized in Table 1. Preliminary experiments had shown that a greater degree of purification was obtained using sequential $\left(\mathrm{NH}_{4}\right)_{2} \mathrm{SO}_{4}$ precipitation (119-fold) than that obtained by Amicon ultrafiltration (25-fold). The yield of enzyme from crude culture supernatant by $\left(\mathrm{NH}_{4}\right)_{2} \mathrm{SO}_{4}$ precipitation varied between batches from 60 to $90 \%$.

Chromatography of $8 \mathrm{ml}\left(\mathrm{NH}_{4}\right)_{2} \mathrm{SO}_{4}$-precipitated enzyme, after dialysis against $0 \cdot 1 \mathrm{M}$ sodium phosphate buffer ( $\mathrm{pH}$ 6), on Sephadex G-200 and elution with the same buffer gave a single peak of activity which was eluted just before the major protein peak and 
Table 1. Purification of $P$. acnes hyaluronate lyase from $1.5 \mathrm{l}$ of crude culture supernatant

\begin{tabular}{|c|c|c|c|c|}
\hline Fraction & $\begin{array}{c}\text { Total } \\
\text { protein }(\mathrm{mg})\end{array}$ & $\begin{array}{l}10^{3} \times \text { Total } \\
\text { activity* }\end{array}$ & $\begin{array}{l}10^{3} \times \text { Specific } \\
\text { activity } \dagger\end{array}$ & $\begin{array}{l}\text { Purification } \\
\text { factor }\end{array}$ \\
\hline $\begin{array}{l}\text { I. Crude culture super- } \\
\text { natant }\end{array}$ & 33000 & 20190 & 0.6 & - \\
\hline $\begin{array}{l}\text { II. } 40 \text { to } 50 \% \text { satn } \\
\left(\mathrm{NH}_{4}\right)_{2} \mathrm{SO}_{4}\end{array}$ & 186 & 13240 & $71 \cdot 2$ & 119 \\
\hline III. Sephadex G-200 & $24 \cdot 5$ & 10600 & 433 & 722 \\
\hline $\begin{array}{l}\text { IV. } 40 \text { to } 50 \% \text { satn } \\
\left(\mathrm{NH}_{4}\right)_{2} \mathrm{SO}_{4}\end{array}$ & 12 & 7070 & 590 & 983 \\
\hline $\begin{array}{l}\text { V. Sephadex G-100 } \\
\text { (second step) }\end{array}$ & $2 \cdot 43$ & 2630 & 1080 & 1800 \\
\hline VI. CM-Sephadex C-50 & $0 \cdot 102$ & 790 & 7750 & 12920 \\
\hline
\end{tabular}

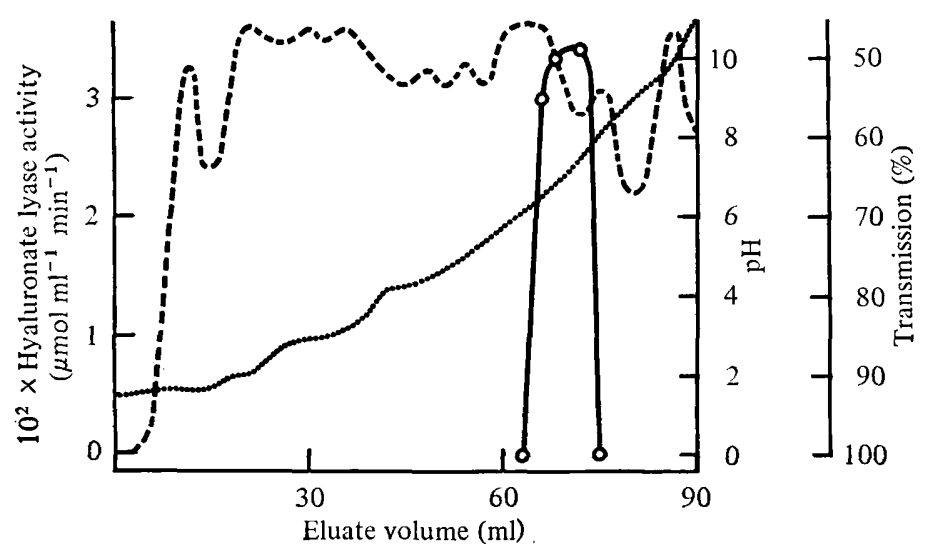

Fig. 1. Elution profile of hyaluronate lyase from the isoelectric focusing column: $O$, hyaluronate lyase activity $\left(\mu \mathrm{mol} N\right.$-acetylglucosamine released $\left.\mathrm{ml}^{-1} \mathrm{~min}^{-1}\right) ;-. .-$, protein concentration (transmission at $280 \mathrm{~nm}) ; \cdots, \mathrm{pH}$. For details, see Methods.

separated from the void volume proteins. This procedure resulted in a $53 \%$ yield with a purification factor of 722 . Concentration of G-200 column fractions, with hyaluronidase activity, by $\left(\mathrm{NH}_{4}\right)_{2} \mathrm{SO}_{4}$ precipitation gave a further increase in specific activity of the enzyme. Chromatography of $6 \mathrm{ml}$ fraction IV enzyme on Sephadex G-100, with $0 \cdot 1 \mathrm{M}$ sodium phosphate buffer ( $\mathrm{pH} \mathrm{6)}$ ) as eluant was repeated until the enzyme peak corresponded to the major protein peak. This preparation (fraction $\mathrm{V}$ ) was concentrated and dialysed by ultrafiltration and subjected to ion-exchange chromatography on CM-Sephadex C-50. A major peak of anionic protein emerged without retardation; a minor protein peak was eluted with $0.15 \mathrm{M}-\mathrm{NaCl}$ and this contained all the enzyme activity. Fractions with constant specific activity (per mg protein) were combined and designated purified fraction VI enzyme. The overall yield of hyaluronidase was $4 \%$ and the purification factor from the original crude culture supernatant was about 13000 .

In preliminary experiments using crude enzyme preparations which had been concentrated by $\left(\mathrm{NH}_{4}\right)_{2} \mathrm{SO}_{4}$ precipitation and subjected once to Sephadex G-200 gel filtration, the hyaluronidase activity appeared as two distinct peaks when subjected to ion-exchange chromatography on CM-Sephadex C-50 in 50 mM-sodium phosphate buffer (pH 6.0). The first minor peak was eluted at $0.06 \mathrm{M}-\mathrm{NaCl}$ and the second peak at $0.2 \mathrm{M}-\mathrm{NaCl}$. However, electrofocusing of crude enzyme preparations failed to reveal more than one peak of activity (Fig. 1) with a pI of 7.0 $\pm 0 \cdot 5$. 
Table 2. Lipase and acid phosphatase activities of the fractions obtained during the purification of $P$. acnes hyaluronidase

\begin{tabular}{|c|c|c|}
\hline \multirow[b]{2}{*}{ Fraction } & \multicolumn{2}{|c|}{ Total activity } \\
\hline & Lipase" & Acid phosphatase $\dagger$ \\
\hline I & $23 \cdot 1$ & $16 \cdot 5$ \\
\hline II & $6 \cdot 53$ & 0.242 \\
\hline III & $3 \cdot 8$ & 0.212 \\
\hline IV & 0.96 & 0.0068 \\
\hline $\mathrm{V}$ & 0 & 0 \\
\hline VI & 0 & 0 \\
\hline
\end{tabular}

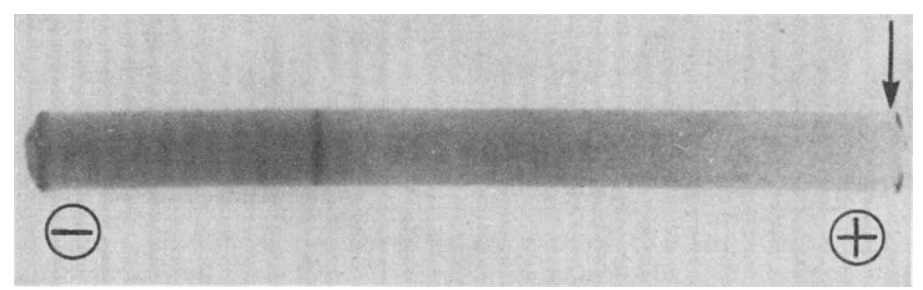

Fig. 2. Polyacrylamide disc gel electrophoresis $(7 \%$ gel) of fraction VI hyaluronate lyase using Tris/glycine buffer ( $\mathrm{pH} 9.5)$ and $4 \mathrm{~mA}$ per tube for $1 \mathrm{~h}$. The purified lyophilized enzyme (10 $\mu \mathrm{g})$ resolved as a single band, suggesting it was homogeneous. The arrow indicates the position of the bromophenol blue marker.

Only one peak of activity was found when relatively pure preparations were subjected to ion-exchange chromatography on CM-Sephadex C-50.

\section{Lipase, acid phosphatase and protease activity of the hyaluronidase fractions}

Propionibacterium acnes $\mathrm{P}-37$ produced exocellular lipase, acid phosphatase and protease. The activities of these enzymes were assayed in the various fractions during the purification of hyaluronidase. A low protease activity was present in the medium during the exponential phase of growth, but protease was not detected in the culture supernatant during the stationary phase, in the 40 to $50 \%\left(\mathrm{NH}_{4}\right)_{2} \mathrm{SO}_{4}$ fraction II or in fraction III. Lipase and acid phosphatase activities were separated from hyaluronidase either by $\left(\mathrm{NH}_{4}\right)_{2} \mathrm{SO}_{4}$ precipitation alone or with additional gel filtration (Table 2).

\section{Homogeneity and molecular weight}

The purified enzyme was homogeneous as shown by disc gel electrophoresis (Fig. 2). The molecular weight of the enzyme as determined by Sephadex gel filtration was 85110 . Examination of the purified enzyme by SDS-polyacrylamide gel electrophoresis revealed two bands: a minor, slow moving component with a molecular weight of about 126000 , and a major, but diffuse, band with a molecular weight of 79430 .

\section{Preliminary characterization of the P. acnes hyaluronidase}

Effect of $\mathrm{pH}$ on activity. The effect of $\mathrm{pH}$ on hyaluronidase activity was determined by incubating fraction VI enzyme $\left(100 \mu \mathrm{l}\right.$, about $\left.7 \mu \mathrm{g} \mathrm{ml}^{-1}\right)$ at various $\mathrm{pH}$ values between 5.8 and $7 \cdot 2$ for $15 \mathrm{~min}$ at $37^{\circ} \mathrm{C}$, using $0 \cdot 1 \mathrm{M}-\mathrm{MES}$ (pH 5.8 to 6.6) and $0.1 \mathrm{M}-\mathrm{MOPS}$ (pH 6.6 to 7.2). The optimum $\mathrm{pH}$ for activity was 6.4 and no activity was detected above $\mathrm{pH} 6.8$. Partially purified fraction III hyaluronidase had a broad $\mathrm{pH}$ optimum (pH 5.4 to 6.4 ) in $0.1 \mathrm{M}$-sodium acetate buffer but in $0.1 \mathrm{M}$-sodium phosphate buffer its $\mathrm{pH}$ optimum was between 6.6 and $6 \cdot 8$. Activity in $0 \cdot 1 \mathrm{M}$-sodium phosphate buffer was low at all $\mathrm{pH}$ values tested. 


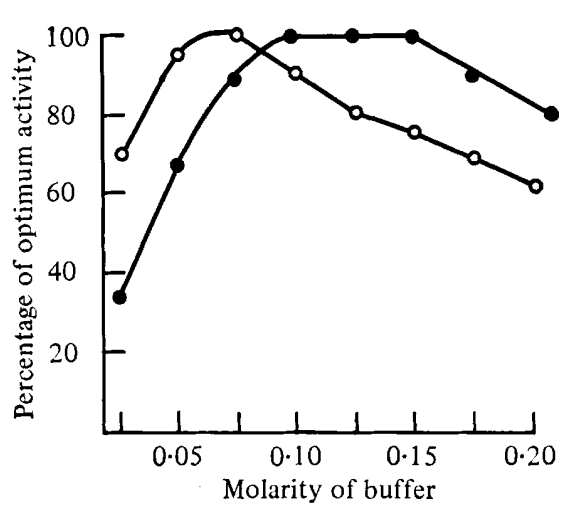

Fig. 3

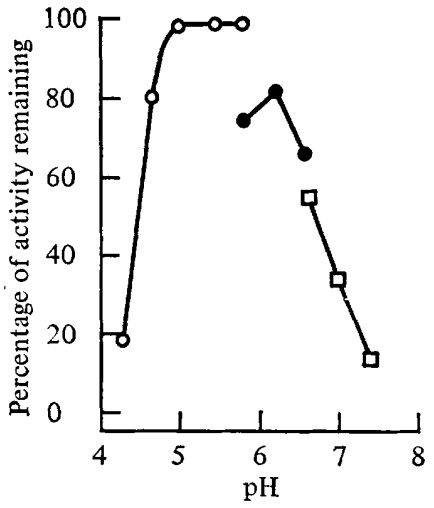

Fig. 4

Fig. 3. Effect of the molarity and type of buffer on the activity of hyaluronate lyase. Fraction V enzyme was assayed at pH 6.4 in MES (O) and acetate $(O)$ buffers from 0.025 to $0.2 \mathrm{M}$. Results are expressed as a percentage of the optimum activity in each buffer.

Fig. 4. Effect of pH on the stability of hyaluronate lyase. Fraction VI enzyme $\left(0.5 \mathrm{ml}, 7 \mu \mathrm{g} \mathrm{ml}^{-1}\right)$ was incubated for $1 \mathrm{~h}$ at $37^{\circ} \mathrm{C}$ at $\mathrm{pH}$ values between 4 and 8 . The activity remaining was then determined in $0.2 \mathrm{M}-\mathrm{MES}$ ( $\mathrm{pH} \mathrm{6.4)}$. Results are expressed as the percentage of activity remaining compared with a control tube in $0 \cdot 1 \mathrm{M}$-acetate buffer $(\mathrm{pH} 5 \cdot 8)$ at $4{ }^{\circ} \mathrm{C}$. Buffers were: $0,0 \cdot 1 \mathrm{M}$-sodium acetate (pH 4.0 to 5.8); $0,0 \cdot 1$ M-MES (pH 5.8 to 6.6); $\square, 0 \cdot 1$ M-MOPS (pH 6.6 to 8.0).

Effect of molarity and nature of the buffer on activity. The activity of $P$. acnes hyaluronidase was affected by both the type and molarity of the buffer used in the assay system. At pH 6.4 maximum activity was obtained in acetate buffer between 0.05 and $0.1 \mathrm{M}$ and the activity in MES was maximal between 0.1 and $0.15 \mathrm{M}$ (Fig. 3). Thus, the ionic strength, $\mathrm{pH}$ and also the nature of the buffer affect the apparent activity of the hyaluronidase. Further studies are necessary to determine the exact nature of the effect of these variables on the enzyme activity.

Stability. The enzyme was stable at slightly acid $\mathrm{pH}$, below the optimal $\mathrm{pH}$ for activity, (Fig. 4) and retained $100 \%$ activity in $0.1 \mathrm{M}$-acetate buffer between $\mathrm{pH} 5$ and $5 \cdot 8$. However, it was not thermostable, being completely inactivated by heating at $50{ }^{\circ} \mathrm{C}$ for $15 \mathrm{~min}$ in $0 \cdot 1 \mathrm{~m}$-acetate buffer at $\mathrm{pH} 5 \cdot 8$.

Activity against chondroitin 4- and 6-sulphates and dermatan sulphate. The purified hyaluronidase was weakly active against chondroitin 4- and 6-sulphates but not against dermatan sulphate. The optimal conditions for activity against these potential substrates were not determined.

Paper chromatography of the reaction products. The reaction products obtained from the degradation of hyaluronic acid by the $P$. acnes enzyme, $S$. aureus hyaluronate lyase and testicular hyaluronidase were analysed by paper chromatography. The $P$. acnes and $S$. aureus enzymes each produced a single violet $\operatorname{spot}\left(R_{F} 0 \cdot 57\right)$ when tested with the $p$-dimethylaminobenzaldehyde solution. The products of the testicular enzyme activity did not separate into discrete spots, probably because of incomplete degradation of hyaluronic acid by this enzyme. The reaction products were not analysed further. The results suggested that the $P$. acnes enzyme could be tentatively classified as a hyaluronate lyase.

\section{DISCUSSION}

Bacterial enzymes which catalyse the depolymerization of hyaluronic acid by an elimination reaction are lyases. The product of their reaction is $3(\Delta-4,5-\beta-\mathrm{D}-$ glucuronosyl $)-N$ acetyl-D-glucosamine (Dixon \& Webb, 1958). Animal enzymes, however, depolymerize hyaluronic acid to oligosaccharides by hydrolytic scission (Dixon \& Webb, 1958). The $P$. acnes enzyme described here was tentatively classified as a hyaluronate lyase. 
It has been reported (Smith \& Willet, 1968; Hoeffler, 1977) that a high percentage of $P$. acnes isolates show 'chondroitin sulphatase' activity. However, it is possible that the activity measured was a depolymerization by hyaluronate lyase since the assay method used in both studies was based on the appearance of clear zones surrounding colonies when undegraded substrate in agar plates was precipitated with acid albumin. Chondrosulphatases catalyse the desulphation of chondroitin sulphates (Dixon \& Webb, 1958) and are determined by measuring the release of inorganic sulphate (Yamagata et al., 1968). The enzymes which depolymerize chondroitin sulphates are either chondroitinases or chondroitin sulphate lyases.

Examination of the purified enzyme preparation by SDS-polyacrylamide gel electrophoresis revealed two protein bands, one major with a molecular weight of 79430 and one minor with a molecular weight of about 126000 . The molecular weight of $P$. acnes hyaluronate lyase was estimated to be 85110 by gel filtration on Sephadex G-100 and therefore the major protein band (79430) is probably the hyaluronate lyase. The presence of a contaminating protein having a molecular weight of 126000 was unlikely after repeated chromatography of the enzyme preparation on Sephadex G-200 and G-100 during the purification procedure, so it is concluded that the preparation is homogeneous. The minor protein band was possibly an artifact produced in the system by incomplete reduction of the enzyme molecule by 2-mercaptoethanol or insufficient SDS-binding. Although the yield of $P$. acnes hyaluronate lyase was only $4 \%$, this compares favourably with the $3 \%$ yield obtained by Rautela \& Abramson (1973) for the hyaluronate lyase of Staphylococcus aureus.

The apparent activity of $P$. acnes hyaluronate lyase was affected by the molarity of the buffer used in the assay system, as are other hyaluronidases (Rogers, 1971). The pH optimum of 6.4 and the temperature instability of the purified enzyme are in agreement with the results of Puhvel \& Reisner (1972), using crude exocellular product preparations of P. acnes hyaluronidase.

In previous studies on hyaluronidases from various sources, different assay methods have been used (Aronson \& Davidson, 1967; Rautela \& Abramson, 1973; Abramson, 1967) and the difficulty of comparing the various activities, even when the same method has been used, has been discussed previously (Puhvel \& Reisner, 1972). The American Pharmaceutical Association (1975) has a national formulary unit (NFU) of hyaluronidase activity but uses a mammalian testicular enzyme as standard. As the colorimetric assay of the $N$-acetylglucosamine end-group is affected by the chain length of the $N$-acetylamino end-group sugar (Reissig et al., 1955) and as the reaction products of the bacterial and testicular enzymes differ (see above), it was not possible to relate the units of enzyme activity used in this study to the NFU. Hyaluronate lyases are produced by a number of micro-organisms Staphylococcus, Streptococcus, Clostridium and Flavobacterium spp. (Rogers, 1971). The possible role of hyaluronate lyase as a 'spreading factor' (Abramson, 1972) in the pathogenesis of disease has been widely documented with particular reference to the staphylococcal enzymes (Abramson, 1972). The role of $P$. acnes hyaluronate lyase in both normal and pathologically involved skin is yet to be determined and it is important to know whether the enzyme is produced by $P$. acnes in vivo. The purified exoenzyme now offers a possible line of investigation, using specific fluorescein-labelled antibodies to determine whether $P$. acnes hyaluronate lyase is present in follicles of both normal and acne skin.

This work was generously supported by a grant from the A. H. Robins Co., and we wish to thank Dr J.S. Templeton and Mr F. S. Walker of that company for their interest throughout. 


\section{REFERENCES}

Abramson, C. (1967). Staphylococcal hyaluronate lyase: multiple electrophoretic and chromatographic forms. Archives of Biochemistry and Biophysics 121, 103-106.

Abramson, C. (1972). In The Staphylococci, pp. 200 205. Edited by J. A. Cohen. New York: Wiley Interscience.

American Pharmaceutical Association. (1975). The National Formulatory NFXIV, pp. 952-954. New York: American Pharmaceutical Association.

Aronson, N. N. \& Davidson, E. A. (1967). Lysosomal hyaluronidase from rat liver. Journal of Biological Chemistry 242, 437-440.

BesSeY, O. A., Lowry, O. H. \& Brock, M. J. (1946). A method for the rapid determination of alkaline phosphatase with five cubic millimeters of serum. Journal of Biological Chemistry 164, 321-329.

Davis, B. J. (1964). Disc electrophoresis II. Method and application to human serum proteins. Annals of the New York Academy of Sciences 121, 404 427.

Dixon, M. \& WebB, E. C. (1958). Enzymes. London, New York \& Toronto: Longmans, Green.

Dole, V. P. \& Meinertz, H. (1960). Microdetermination of long chain fatty acids in plasma and tissues. Journal of Biological Chemistry 235, 2595-2599.

HoEfFler, U. (1977). Enzymatic and haemolytic properties of Propionibacterium acnes and related bacteria. Journal of Clinical Microbiology 6, 555-558.

Kirschbaum, J. O. \& Kligman, A. M. (1963). The pathogenic role of Corynebacterium acnes in acne vulgaris. Archives of Dermatology 88, 832-833.

Linker, A., Meyer, K. \& Hoffman, P. (1956). The production of unsaturated uronides by bacterial hyaluronidases. Journal of Biological Chemistry 219, 13-25.

Marples, R. R. \& McGinley, K. J. (1974). Corynebacterium acnes and other anaerobic diphther- oids from human skin. Journal of Medical Microbiology 7, 349-357.

MARPles, R. R., Downing, D. T. \& Kligman, A. M. (1971). Control of free fatty acids in human surface lipids by Corynebacterium acnes. Journal of Investigative Dermatology 56, 127-131.

Millet, J. (1970). Characterization of proteinases excreted by Bacillus subtilis Marburg strain during sporulation. Journal of Applied Bacteriology 33, 207-219.

Puhvel, S. M. \& Reisner, R. M. (1972). The production of hyaluronidase (hyaluronate lyase) by Corynebacterium acnes. Journal of Investigative Dermatology 58, 66-70.

Rautela, G. S. \& Abramson, C. (1973). Crystallisation and partial characterisation of Staphylococcus aureus hyaluronate lyase. Archives of Biochemistry and Biophysics. 158, 687-694.

Reisner, R. M., Silver, D. L., Puhvel, S. M. \& STERNBERG, T. H. (1968). Lipolytic activity of Corynebacterium acnes. Journal of Investigative Dermatology 51, 190 196.

Reissig, J. L., Strominger, J. L. \& Leloir, L. F. (1955). A modified colorimetric method for the estimation of $\mathrm{N}$-acetylamino sugars. Journal of Biological Chemistry 217, 956-966.

Rogers, J. H. (1971). Biochemists Handbook, pp. 242-245. Edited by C. Long, E. J. King \& W. M. E. Sperry. London: F. N. Spon.

Smith, R. F. \& Willet, N. P. (1968). Rapid plate method for screening hyaluronidase and chondroitin sulphatase producing micro-organisms. Applied Microbiology 16, 1434-1436.

Weber, K., Pringle, J. R. \& Osborn, M. (1972). Measurement of molecular weights by electrophoresis on SDS-acrylamide gel. Methods in Enzymology 26, 3-27.

Yamagata, T., SaIto, H., Habuchi, O. \& Suzuki, S. (1968). Purification and properties of bacterial chondroitinases and chondrosulphatases. Journal of Biological Chemistry 243, 1523-1535. 